\title{
AGRONOMIC TRAIT AND GENETIC ANALYSIS OF LATVIAN FLAX GERMPLASM
}

\author{
Dainis Ruņgis ${ }^{1}$, Linards Lubinskis ${ }^{1}$, Veneranda Stramkale ${ }^{2}$ \\ 1- Genetic Resource Centre, LSFRI „Silava”. Rīgas 111, Salaspils, LV-2169, Latvia \\ 2- Agriculture Science Centre of Latgale \\ Kulturas sq. 1a, Vilani, Vilani distr., LV 4650, Latvia
}

\begin{abstract}
There is a long history of flax cultivation in Latvia, and breeding programs were active until 1970 's, when flax breeding in Latvia was halted. Since 1992, the Agriculture Science Centre of Latgale (ASCL) has repatriated Latvian flax germplasm from various genebanks, as well as renewed limited breeding activities in flax. Currently, the ASCL holds a collection of 497 flax accessions, as well as 9865 accessions of various lines and hybrids developed at the LLZC since 1993. To assist in the characterization of this Latvian flax germplasm, we have utilised DNA markers to assess genetic diversity and relatedness, as well as surveying functional polymorphism. We have utilised Simple sequence repeat (SSR) markers developed from both genomic libraries as well as expressed sequences. The results of the DNA marker survey were utilised to determine the genetic polymorphism and relatedness within Latvian flax germplasm, and these results were compared with the analysis of agronomic traits carried out in field trials at the ASCL. The development of DNA markers linked to traits of agronomic importance will assist in the development of a Latvian flax breeding program. The use of DNA marker technology will allow more efficient assessment and rational utilization of Latvian flax germplasm.
\end{abstract}

Keywords: flax breeding, DNA markers, characterisation and evaluation.

\section{Introduction}

During the 1920's and 1930's, flax (Linum usitatissinum L.) was grown throughout the territory of the Republic of Latvia. Flax breeding was undertaken at Priekuḷu, Stende and Ošupe breeding stations, and many flax varieties were developed, including 'Balva', 'Rota', 'Rota 2', 'Priekuļu 665', 'Priekuḷu uzlabotie', 'Ošupe 30', 'Ošupe 31', etc. In the 1970's, flax breeding activities were discontinued in Latvia [1].

Currently, the flax varieties grown in Latvia are foreign varieties, which are not suited to Latvian soil and climatic conditions, and do not ensure stable flax fibre and seed yield. Successful development of the Latvian flax industry requires the creation of new, locally adapted varieties of flax.

Since 1992, the ASCL has actively engaged in research on flax fibre, oil and genetic resources, as well as repatriation, propagation, research, preservation and maintenance of a Latvian flax collection. A large part of the collection comprises of varieties and lines of Latvian origin repatriated from the N. Vavilov All-Russian Plant Institute, the Russian Flax Research Institute, and German gene banks. The ASCL flax collection also contains 497 flax accessions from other countries, including 427 fibre accessions and 70 oil accessions. Flax breeding activities were started at the ASCL in 1993, and accessions with valuable qualitative and quantitative characteristics are used for breeding and hybridisation. The flax collection also contains 9865 lines and hybrids of Latvian origin developed at the ASCL in recent years. Only a small proportion of the resulting hybrids and lines have been evaluated, the other varieties and lines are maintained in the ASCL gene bank.

The use of DNA markers has become widespread in the study of a wide range of crop species. In contrast to phenotypic traits and markers, they have the advantage of not being influenced by environmental conditions; they reveal a higher level of polymorphism; and markers linked to specific genes or quantitative trait loci (QTLs) can be characterized. DNA markers are utilised in characterization of genetic resource collections and have been integrated into 
breeding programs for various crop species. While not as widely studied as other crop species, DNA markers have been extensively studied in flax, and a range of molecular tools have been developed and utilised, including SSR markers, genetic linkage maps, QTL studies, microarray and proteomics studies $[2 ; 3,4,5]$.

This study utilised DNA markers to characterize a subset of the best established Latvian oil and fibre flax varieties and lines, and these genotyping results were compared to agronomically important traits measured in field trials of these varieties.

\section{Materials and Methods}

The flax material analysed included older Latvian cultivars, which were developed before the 1950 's, as well as newly developed breeding lines, derived from crosses between these old Latvian varieties and more modern, foreign cultivars, as well as crosses exclusively between modern, foreign cultivars.

The flax material was planted in the field at the ASCL, and the following agronomic properties assessed for: plant height (total and technical), yield (straw and seed), boll number, seed count, 1000 seed weight, bast content, oil content, unretted bast and shive yield. Agronomic trait values reported in this study were measured in 2010.

Seed material was obtained from the ASCL collection. Seeds were germinated and genomic DNA was extracted from 1-2 week old seedlings using a modified CTAB protocol [6]. Samples were ground in a mortar with $500-800 \mu 12 \mathrm{x}$ CTAB buffer (heated to $65^{\circ} \mathrm{C}$ ), and transfered to $1.5 \mathrm{ml}$ centrifuge tubes. After incubation at $65^{\circ} \mathrm{C}$ for $15-20 \mathrm{~min}$., chloroform (1:1) was added and mixed for 3-5 min. The tubes were centrifuged for $10 \mathrm{~min}$ at $13000 \mathrm{rpm}$., the supernatant tranfered to new tubes and 0.2 volumes $5 \mathrm{x}$ CTAB buffer $\left(65^{\circ} \mathrm{C}\right)$ added. Samples were gently mixed for 3-5 min and then incubated for $10 \mathrm{~min}$ at $65^{\circ} \mathrm{C}$. Chloroform (1:1) was added and mixed for 3-5 min., then samples were centrifuged for $10 \mathrm{~min}$ at 13000 rpm. Supernatant was transfered to a new tube, 0.7 volumes of isopropanol added, gently mixed and incubated for 20-30 $\mathrm{min}$ at room temperature. Tubes were centrifuged for $10 \mathrm{~min}$, the supernatant removed, and the remaning pellet washed twice with $70 \%$ ethanol $\left(-20^{\circ} \mathrm{C}\right)$, centrifuging for 2-3 min between washes. The pellet was air-dried, and resuspended in $75 \mu 1$ TE buffer. DNA from 6 individuals of each cultivar was extracted and analysed separately.

Nine SSR markers were used to genotype these cultivars ( $\mathrm{Lu} \mathrm{002,} \mathrm{Lu} \mathrm{013,} \mathrm{Lu} \mathrm{021,} \mathrm{Lu} \mathrm{023,}$ Lu 031, Lu 032, Lu44E4, Lu178, Lu765B) [2, 5, 7]. The forward primer was synthesised with a 6-FAM, HEX or NED fluorescent label to allow visualisation of amplification products on a fluorescent sequencer (Table 1).

SSR locus amplification was carried out using the following PCR conditions: $95^{\circ} \mathrm{C}$ for $3 \mathrm{~min}$, 38 cycles of $95^{\circ} \mathrm{C}$ for $30 \mathrm{sec}, 55^{\circ} \mathrm{C}-30 \mathrm{sec}, 72^{\circ} \mathrm{C}-30 \mathrm{sec} ; 72^{\circ} \mathrm{C}-10 \mathrm{~min}$; in a total volume of reaction $20 \mu 1$ containing $50 \mathrm{ng}$ template DNA, 1x PCR buffer, $2 \mathrm{mM} \mathrm{MgCl} 2,0.2 \mathrm{mM}$ dNTP mix, $0.5 \mathrm{U} \mathrm{Taq}$ polymerase (Fermentas), $0.5 \mathrm{mM}$ of forward (labelled) and reverse primers. Amplification fragments were separated on an ABI Prism 3130xl Avant Genetic Analyzer (Applied Biosystems) and analyzed with GeneMapper 3.5. Population analyses were performed with GenAlEx version 6.4 [8], and dendrograms constructed using MEGA version 4 [9]. 
SSR markers utilised in this study

Table 1.

\begin{tabular}{|c|c|c|c|}
\hline Locus & Primer name & Primer sequence & Repeat motif \\
\hline \multirow{2}{*}{$\mathbf{L U 0 0 2}^{\mathrm{a}}$} & LU002F & AACCGGAACTTTCGGCTGAG & \multirow{2}{*}{$(\mathrm{TC})_{18}$} \\
\hline & LU002R & GGTTGGAGTAATCGCCGGAG & \\
\hline \multirow{2}{*}{$\mathbf{L U 0 1 3}^{\mathrm{a}}$} & LU013F & TGTGCCAATAGCCATGTGAG & \multirow{2}{*}{$(\mathrm{AC})_{4}(\mathrm{AG})_{18}$} \\
\hline & LU013R & GTATGGCTTCCTATGGGCTAAC & \\
\hline \multirow{2}{*}{ LU021 $^{\text {a }}$} & LU021F & CCGAGTCCGAAAGAATCTGG & \multirow{2}{*}{$(\mathrm{GA})_{15}(\mathrm{~A})_{4}$} \\
\hline & LU021R & CAGCTCCCATTGTTGTTCCC & \\
\hline \multirow{2}{*}{$\mathbf{L U 0 2 3}^{\mathrm{a}}$} & LU023F & CATGACCATGTGATTAGCATCG & \multirow{2}{*}{$(\mathrm{CA})_{8}(\mathrm{GA})_{22}$} \\
\hline & LU023R & CATAGGAGGTGGGTTGCTGC & \\
\hline \multirow{2}{*}{$\mathbf{L U 0 3 1}^{\mathrm{a}}$} & LU031F & CACGAATCTCTCCCAGACA & \multirow{2}{*}{$(\mathrm{TC})_{8}$} \\
\hline & LU031R & GAGAGTTTAGGGTATGCACTGA & \\
\hline \multirow{2}{*}{$\mathbf{L U 0 3 2}^{\mathrm{a}}$} & LU032F & GAAAAGGAAGGCTTAGAAGAAGAAG & \multirow{2}{*}{$(\mathrm{AG})_{10}$} \\
\hline & LU032R & AGTTTCTCAATACACAGATCGAAGG & \\
\hline \multirow{2}{*}{$\mathrm{Lu}_{4} \mathrm{E} 4^{\mathrm{b}}$} & Lu44E4F & TCCTCAACCCACCACCTAAA & \multirow{2}{*}{ Not reported } \\
\hline & Lu44E4R & ATCGTGCAGTCTTGCAACC & \\
\hline \multirow{2}{*}{$\mathrm{Lu} 765 B^{c}$} & Lu765BF & CCTCATTCCGCTCAGCAA & \multirow{2}{*}{$(\mathrm{TTC})_{8}$} \\
\hline & Lu765BR & CGAAAATGGGGAAGATGATG & \\
\hline \multirow{2}{*}{$\mathbf{L u 1 7 8}^{\mathrm{c}}$} & $\mathrm{Lu} 178 \mathrm{~F}$ & CAAGGGAGTGCTGCTCTGAT & \multirow{2}{*}{$(\mathrm{TC})_{9}$} \\
\hline & Lu178R & ATTGCGAGCAACAACAACAG & \\
\hline
\end{tabular}

Cited in: $a-[2], b-[7], c-[5]$.

SSR marker analysis

\section{Results and discussion}

The number of alleles detected by the 9 analysed markers ranged from 4-16 (average 8.56); however, the distribution of these alleles was uneven, as seen by the low figures for the effective number of alleles, which ranged from 1.13-4.58 (average 2.68). The observed heterozygosity ranged from 0.00-0.95 (average 0.42), while the expected heterozygosity ranged from 0.12-0.78 (average 0.55). The inbreeding coefficient $F$, ranged from -0.58-1.00 (average 0.23), indicating an overall excess of homozygotes, which is to be expected from a mainly inbreeding species, that has been homogenised by line selection over multiple generations. One interesting observation was that the SSR markers developed from expressed portions of the genome (Lu178 and Lu765B) were the most highly polymorphic markers (allele numbers were 10 and 16, respectively). However, most of these alleles were of low frequency, as reflected in the number of effective alleles (1.93 and 3.44, respectively) (Table 2).

The level of genetic polymorphism was compared between the old cultivars and the new lines. The mean number of alleles in the cultivars was 4.56 , while in the lines then mean number of alleles was 7.44. This difference was a function of the number of individuals analysed, with 121 individuals from the lines analysed, and only 33 from the cultivars. When 33 individuals were randomly chosen from the lines, the mean number of alleles was similar (4.67 in the lines, 4.56 in the cultivars). Analysing the full set of data, the other measures of genetic diversity were similar between the cultivars and lines. The number of alleles with a frequency over 5\% was 2.67 and 3.00 respectively, the number of effective alleles was 2.44 and 2.46, and the expected heterozygosity was 0.52 in both groups. The Nei genetic distance between 
all analysed individuals was calculated, and a principal co-ordinates analysis plot calculated (Fig. 1). It can be seen that there is no clear differentiation between the cultivars and lines, and that the genetic diversity of the old cultivars has been retained in the newly developed lines. This low differentiation between the two groups was confirmed by analysis of molecular variance (AMOVA), where $95 \%$ of the genetic variance was within the groups, and only $5 \%$ between $(\mathrm{p} \leq 0.001)$.

Table 2.

\section{Genetic parameters of analysed SSR markers}

\begin{tabular}{|c||c|c|c|c|c|c|c|c|c|c|}
\hline Locus & LU002 & LU013 & LU032 & Lu21 & Lu23 & Lu31 & Lu44E4 & Lu178 & Lu765B & $\begin{array}{c}\text { Average } \\
\text { over } \\
\text { loci }\end{array}$ \\
\hline \hline $\begin{array}{c}\text { Number of } \\
\text { alleles }\end{array}$ & 5 & 9 & 7 & 5 & 7 & 4 & 14 & 10 & 16 & 8.556 \\
\hline $\begin{array}{c}\text { Effective } \\
\text { number of } \\
\text { alleles }\end{array}$ & 1.539 & 4.581 & 2.360 & 1.130 & 4.426 & 2.247 & 2.502 & 1.929 & 3.441 & 2.684 \\
\hline $\begin{array}{c}\text { Observed } \\
\text { heterozygosity }\end{array}$ & 0.333 & 0.632 & 0.730 & 0.103 & 0.769 & 0.000 & 0.946 & 0.149 & 0.113 & 0.419 \\
\hline $\begin{array}{c}\text { Expected } \\
\text { heterozygosity }\end{array}$ & 0.350 & 0.782 & 0.576 & 0.115 & 0.774 & 0.555 & 0.600 & 0.481 & 0.709 & 0.549 \\
\hline $\begin{array}{c}\text { Inbreeding } \\
\text { coefficient }\end{array}$ & 0.049 & 0.191 & -0.266 & 0.107 & 0.006 & 1.000 & -0.576 & 0.691 & 0.840 & 0.227 \\
\hline
\end{tabular}

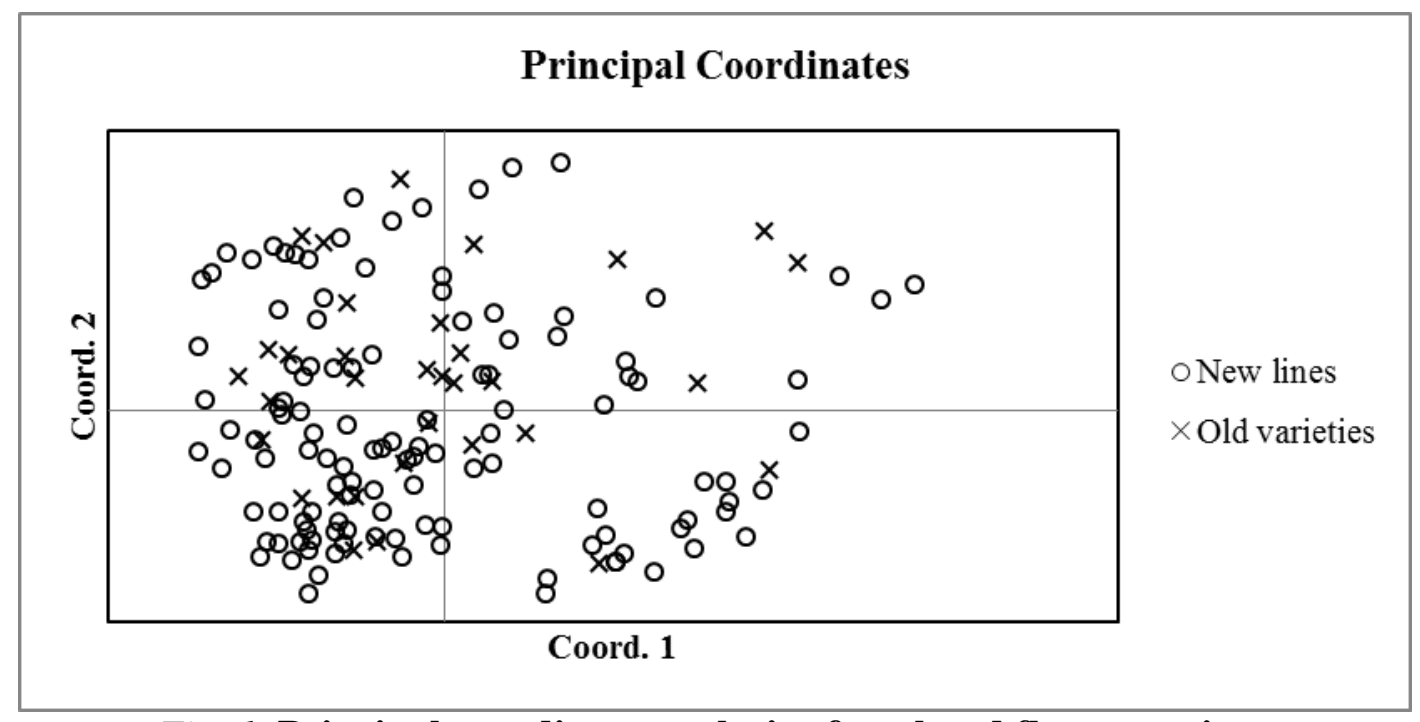

Fig. 1. Principal coordinate analysis of analysed flax accessions

The pairwise Nei genetic distance between the cultivars and lines was calculated, and a dendrogram constructed using the Neighbour-Joining algorithm (Fig. 2). No distinct clusters were identified within the dendrogram, however, lines derived from the same cross tended to cluster closely to each other (but not always), and the old varieties were found to cluster together. This lack of defined clusters within the dendrogram is probably a reflection of the fairly low level of genetic polymorphism, and the low differentiation between the lines and cultivars 


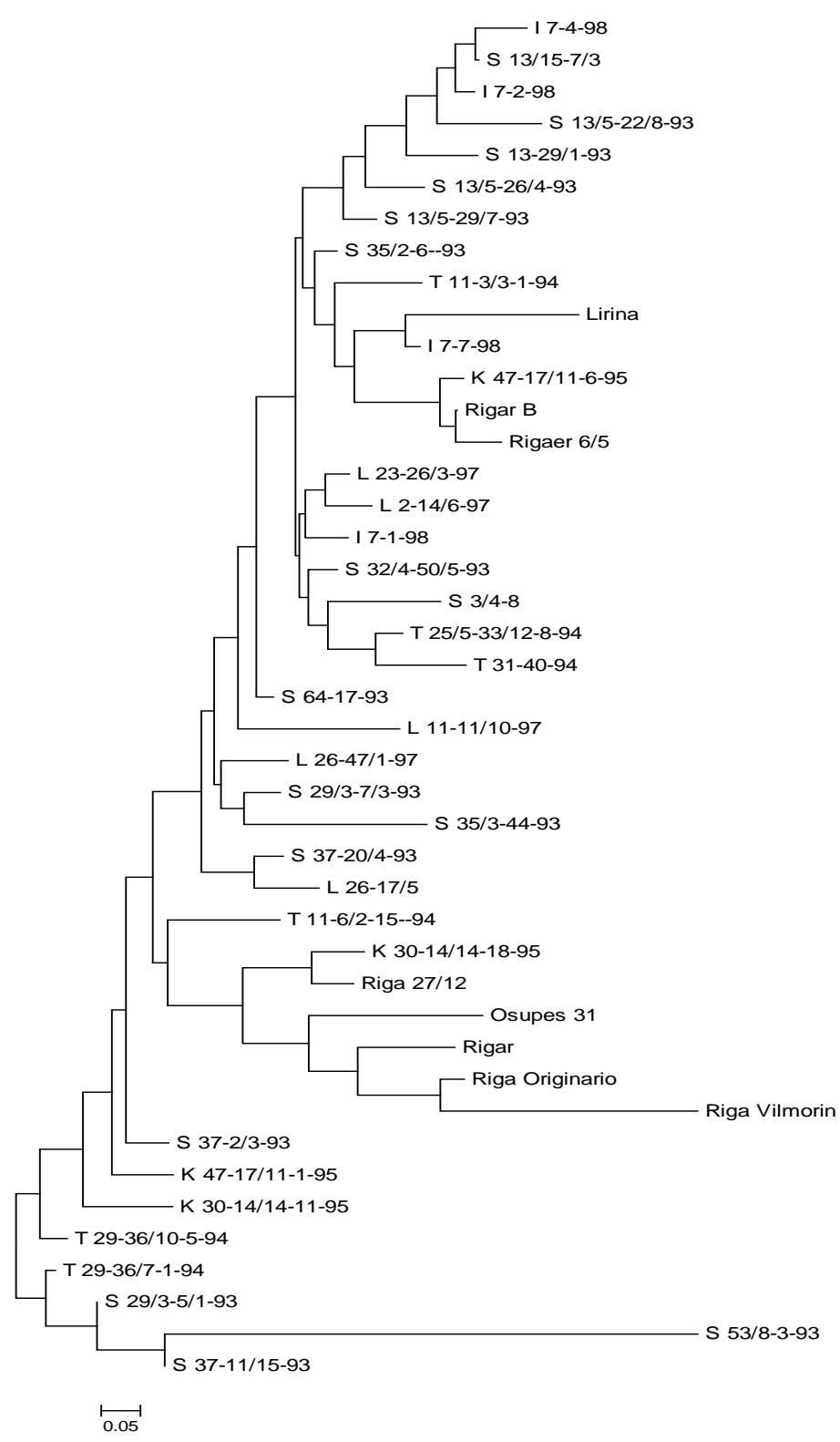

Fig. 2. Neighbour-joining dendrogram of analysed flax accessions

Correlation of genetic analysis with agronomic traits

The lines included in this study were selected for having agronomic properties that are desirable, and that could be potentially utilised in the development of new, locally adapted varieties. Therefore, the agronomic trait values in the lines usually exceeded those of the control varieties (Vega2 and Lirina), particularly for fibre-related traits. Examination and ordering of the agronomic trait data showed that in some cases, lines derived from the same cross yielded the best agronomic trait scores. In particular, lines derived from the cross Blakitnij x Ošupes 31 (K 30) and M-12 x Eva (S 37), were consistently ranked in the top five best lines, especially with regard to fibre traits. The agronomically best performing lines do not show any particular clustering within the dendrogram, and they are not distinct when considering the measures of genetic diversity such as the number of alleles, the number of effective alleles and heterozygosity. The old varieties tended to show better results for such parameters as seed yield, boll number and 1000 seed weight (Table 3). 
Table 3.

Agronomic trait data from 2010 field trials

\begin{tabular}{|c|c|c|c|c|c|c|c|c|c|c|c|}
\hline \multirow[b]{2}{*}{ Variety or line } & \multicolumn{2}{|c|}{ Plant height, cm } & \multicolumn{2}{|c|}{ Yield, $\mathbf{g} / \mathbf{m}^{2}$} & \multirow{2}{*}{$\begin{array}{c}\begin{array}{c}\text { Boll } \\
\text { number }\end{array} \\
\text { per } \\
\text { plant }\end{array}$} & \multirow{2}{*}{\begin{tabular}{|c|}
$\begin{array}{c}\text { Seed } \\
\text { count }\end{array}$ \\
$\begin{array}{c}\text { per } \\
\text { boll }\end{array}$
\end{tabular}} & \multirow{2}{*}{ 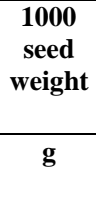 } & \multirow{2}{*}{$\begin{array}{c}\begin{array}{c}\text { Bast } \\
\text { content }\end{array} \\
\%\end{array}$} & \multirow{2}{*}{$\begin{array}{c}\begin{array}{c}\text { Oil } \\
\text { content }\end{array} \\
\% \text { dry } \\
\text { weight }\end{array}$} & \multirow{2}{*}{$\begin{array}{c}\begin{array}{c}\text { Unretted } \\
\text { bast }\end{array} \\
\mathbf{g} / \mathbf{m}^{2}\end{array}$} & \multirow{2}{*}{$\begin{array}{c}\begin{array}{c}\text { Unretted } \\
\text { shives }\end{array} \\
\mathbf{g} / \mathbf{m}^{2}\end{array}$} \\
\hline & total & technical & straw & seed & & & & & & & \\
\hline I7-1-98 & 84.2 & 71.9 & 597 & 128.7 & 5.9 & 8.8 & 4.4 & 27.7 & 43.2 & 260 & 260 \\
\hline I7-2-98 & 85.1 & 74 & 617 & 142.1 & 7.1 & 8.8 & 4.41 & 32.3 & 42 & 260 & 270 \\
\hline I7-4-98 & 89.2 & 78.3 & 540 & 126.1 & 6.9 & 8.5 & 4.28 & 32.7 & 42.2 & 210 & 250 \\
\hline I7-7-98 & 83.9 & 72.2 & 623 & 117.6 & 5.8 & 9 & 4.15 & 31.5 & 40.2 & 220 & 240 \\
\hline K30-14/14/-11-95 & 88.9 & 78.2 & 637 & 96.8 & 6.1 & 8.9 & 3.95 & 35.3 & 46.9 & 290 & 270 \\
\hline K30-14/14-18-95 & 91.6 & 81.7 & 630 & 72.4 & 6.4 & 8.8 & 3.95 & 32.6 & 47.1 & 260 & 300 \\
\hline K47-17/11-1-95 & 80.6 & 68.8 & 553 & 115.9 & 7.2 & 8.6 & 4.08 & 34.8 & 46.6 & 210 & 200 \\
\hline K47-17/11-6-95 & 80.9 & 68.7 & 537 & 112.1 & 8.6 & 8.3 & 4.1 & 32.7 & 44.7 & 200 & 200 \\
\hline L11-11/10-97 & 74.7 & 64.3 & 510 & 126.9 & 8 & 9.1 & 4.72 & 30.9 & 45.6 & 159.8 & 190 \\
\hline L2-14/6-97 & 72.7 & 61.6 & 377 & 99.3 & 6.5 & 8.2 & 3.95 & 30.6 & 42.9 & 170 & 170 \\
\hline L23-26/3-97 & 78.6 & 65.4 & 410 & 82 & 7.9 & 8.3 & 3.73 & 32.5 & 41.6 & 116.3 & 160 \\
\hline L26-47/1-97 & 79.1 & 68.4 & 407 & 80 & 6.7 & 8.2 & 3.33 & 31.8 & 45.6 & 190 & 180 \\
\hline S 13/15-7/3-93 & 79.4 & 69.7 & 5.67 & 81.2 & 6.6 & 9.3 & 4.06 & 29.5 & 43.3 & 26.0 & 32.0 \\
\hline S13/5-22/8-93 & 79.2 & 67.8 & 497 & 62.1 & 8 & 9 & 3.72 & 25.3 & 42.3 & 127.8 & 190 \\
\hline S13/5-26/4-93 & 78.3 & 68.4 & 480 & 97.3 & 6.3 & 8.9 & 3.75 & 32.6 & 42.8 & 173.1 & 190 \\
\hline S13/5-29/7-93 & 79.3 & 70.1 & 453 & 98.7 & 5.5 & 8.9 & 3.8 & 28.7 & 42.5 & 163.4 & 170 \\
\hline S13-29/1-93 & 79.2 & 70.3 & 483 & 77.1 & 5.6 & 8.3 & 3.85 & 29.1 & 42.5 & 190 & 230 \\
\hline S29/3-5/1-93 & 72.4 & 62.4 & 507 & 82.9 & 6.1 & 8.2 & 3.9 & 36.8 & 43.8 & 172.8 & 210 \\
\hline S29/3-7/3-93 & 80.5 & 69.8 & 607 & 79.7 & 6.7 & 8.9 & 3.86 & 35.6 & 43.7 & 220 & 250 \\
\hline S32/4-8-93 & 76.6 & 63.9 & 420 & 75.7 & 8.2 & 8.6 & 3.96 & 32.5 & 42.6 & 210 & 200 \\
\hline S32/4-50-93 & 72.1 & 60.2 & 400 & 71.8 & 8.1 & 8.7 & 3.97 & 35.8 & 43.3 & 127.9 & 130 \\
\hline S35/2-6-93 & 72.5 & 61.4 & 417 & 102.9 & 5.9 & 8.5 & 3.41 & 34.1 & 44.6 & 210 & 160 \\
\hline S35/3-44-93 & 76.8 & 65.7 & 410 & 76.8 & 7.6 & 8.9 & 2.63 & 29.5 & 43.7 & 136.1 & 200 \\
\hline S37-11/15-93 & 86.2 & 73.8 & 543 & 116.6 & 7.1 & 9 & 4.56 & 38.7 & 44.8 & 175.1 & 190 \\
\hline S37-2/3-93 & 78.3 & 66.2 & 507 & 77.9 & 7 & 8.8 & 4.18 & 38.4 & 43 & 190 & 220 \\
\hline S37-20/4-93 & 82.7 & 71.4 & 557 & 72.9 & 6 & 8.5 & 4.56 & 36.1 & 44.6 & 210 & 220 \\
\hline S53/8-3-93 & 80.7 & 71.2 & 507 & 91 & 7.1 & 8.3 & 3.92 & 33.4 & 44.8 & 200 & 150 \\
\hline S64-17-93 & 81.5 & 70.7 & 587 & 135.2 & 7.4 & 8.9 & 4.56 & 30.2 & 44.5 & 250 & 290 \\
\hline T11-13/3-1-94 & 77.9 & 68 & 520 & 98.9 & 5.5 & 8.5 & 4.23 & 32.1 & 43.2 & 210 & 190 \\
\hline T11-6/2-15-94 & 77.5 & 66.4 & 417 & 110.6 & 7.5 & 8.6 & 3.84 & 35.3 & 41.2 & 190 & 170 \\
\hline T25/5-33/12-8-94 & 85.4 & 73.1 & 430 & 65.5 & 5.8 & 8.6 & 3.61 & 31.1 & 44.9 & 240 & 140 \\
\hline T29-36/10-5-94 & 79.2 & 69.6 & 573 & 83.4 & 4.8 & 8.8 & 4.17 & 34 & 42.9 & 230 & 170 \\
\hline T29-36/7-1-94 & 82.4 & 70.7 & 577 & 97.1 & 6.7 & 9.1 & 4.47 & 33.1 & 44.1 & 250 & 150 \\
\hline T31-40-94 & 83 & 69.8 & 480 & 102.7 & 8 & 9.1 & 3.71 & 33.1 & 45.2 & 210 & 150 \\
\hline $\begin{array}{l}\text { Vega 2 } \\
\text { (standard) }\end{array}$ & 71.8 & 61.6 & 500 & 108.6 & 5.6 & 8.1 & 4.59 & 30.1 & 45.4 & 151.4 & 170 \\
\hline Ošupes 31 & 70.9 & 59.5 & 537 & 113.4 & 8.5 & 8.2 & 3.77 & 28.6 & 42 & 190 & 210 \\
\hline Riga $27 / 12$ & 57.7 & 45.6 & 373 & 114.3 & 7.7 & 7.9 & 4.1 & 32.3 & 42.3 & 137.7 & 170 \\
\hline Riga Originario & 59.9 & 47.5 & 460 & 161.3 & 5.7 & 8.2 & 5.25 & 31.1 & 44.1 & 165.9 & 200 \\
\hline Riga Vilmorin & 62 & 51.4 & 397 & 84.8 & 6.9 & 8.6 & 4.73 & 31.2 & 42.7 & 159.9 & 200 \\
\hline Rigaer 6/5 & 65.6 & 51.3 & 390 & 139.5 & 5.7 & 8.2 & 4.94 & 31.9 & 44.4 & 161.9 & 190 \\
\hline Rigar & 61.2 & 48.9 & 360 & 122.4 & 6.8 & 7.7 & 5.86 & 29.2 & 45 & 110.3 & 130 \\
\hline Rigar B & 66 & 53.5 & 410 & 93.7 & 7.1 & 8.2 & 4.49 & 31.5 & 44.3 & 148.2 & 130 \\
\hline
\end{tabular}

Trait values in shaded cells exceed that of standard varieties (Vega 2 and Lirina).

Lines with identical initial letter/number combinations are derived from a single cross 
The level of genetic polymorphism identified with the utilised SSR markers was modest. While the number of alleles detected with the analysed SSR markers is not extremely low, the distribution of the alleles is very uneven, with only 2 or 3 alleles with a frequency above $5 \%$ found at most loci. A fairly low level of polymorphism is found in many crop species, which have been subjected to intensive selection pressures in breeding programs. There was very little genetic differentiation found between the old cultivars and the newly developed lines. This is a reflection of the fact that some of the lines are derived from crosses between these old Latvian cultivars, and more modern foreign cultivars. However, some of the new lines are derived entirely from crosses between foreign cultivars, and these lines are also not genetically differentiated from the old Latvian cultivars. This indicates the narrow genetic base of cultivated flax in general, which has been reported previously [2, 5].

An interesting observation was that the two SSR markers derived from expressed gene sequences (EST-SSRs) (Lu178 and Lu765B) were the most highly polymorphic markers in term of the number of alleles detected. This is surprising, as SSR markers derived from expressed sequences have often been reported to detect a lower level of genetic polymorphism in comparison to SSR markers derived from genomic sequences [10]. This is presumed to be a result of evolutionary constraints upon these repeat sequences due to their proximity to coding sequences. It would be interesting to survey larger amount of flax SSRs derived from expressed sequence to determine if this tendency is maintained.

There was genetic polymorphism detected within all lines and cultivars surveyed. This may be a consequence of the type of flax material included in this study - old cultivars dating from the first half of the $20^{\text {th }}$ century, and breeding lines. It is interesting that most of the alleles detected were of a low frequency, however, they were often found in multiple individuals from a particular line or cultivar, indicating that these rare alleles are probably due to remaining heterozygosity within these lines and cultivars, and not to pollen contamination from other flax lines and cultivars. It is not surprising to find such intra-varietal variation within older cultivars, which were not bred to such strict uniformity as required by modern cultivar registration regulations. Furthermore, this genetic heterogeneity is to be expected in breeding lines, which have not been fully homogenised through many generations of selfpollination.

That fact that the agronomically best performing lines did not show an increased degree of genetic similarity (except for those lines derived from a single cross), can be explained by the fact that the agronomic traits measured are complex, and are probably influenced by a large number of genes. In addition, the dendrogram was not particularly well-resolved, probably due to the low level of genetic polymorphism. Lines derived from the same cross did not always cluster together (e.g. lines derived from the cross I7, S37 and K47). The SSR markers utilised in this study will be useful for monitoring the overall genetic diversity within Latvian flax germplasm and breeding programs. In order to find markers that are linked to traits of agronomic interest, it will be necessary to develop markers based on functional regions of the genome, such as polymorphisms within expressed genes and gene copy number variations. Further work in this area will be the assessment of polymorphism in candidate genes that have been identified from previously published microarray and proteomic studies of fibre development in flax.

\section{Conclusions}

This study was an initial survey of the genetic polymorphism found within the Latvian flax collection using SSR markers. The data obtained will provide a baseline for further characterization and assessment of Latvian flax germplasm. Use of these SSR markers to further investigate the accessions in the flax collection held at the ASCL which have yet to be 
characterised will enable genetically unique and differentiated germplasm to be identified, thus making process of screening for agronomically important traits more efficient.

\section{Acknowledgements}

This project was partly funded by the Latvian Science Council project Nr. 10.0040 „Latvijas atjaunojamo izejvielu - linu un kaņepāju produktu īpašību pētījumi, to pielietošana inovatīvu tehnologiju un jaunu funkcionālu materiālu izstrādei”.

\section{References}

1. Holms, I., Sniedze R. Šķiedraugu selekcija [Fibre crop breeding]. In 'Laukaugu selekcija Latvijā' ['Crop breeding in Latvia'] Holms, I. (ed). Avots, Rīga. (1992) p. 123-130. (in Latvian)

2. Roos-Amsaleg, C., Cariou-Pham, E., Vautrin, D., Tavernier, R., Solignac, M., Molecular Ecology Notes, 2006, v. 6: p.796-799.

3. Roach, M.J., Deyholos, M.K. Microarray analysis of flax (Linum usitatissimum L.) stems identifies transcripts enriched in fibre-bearing phloem tissues. Molecular Genetic and Genomics, 2007, v. 278 p. $149-165$.

4. Hotte. N.S., Deyholos, M.K. A flax fibre proteome: identification of proteins enriched in bast fibres. BMC Plant Biology, 2008, v. 8:52.

5. Cloutier, S., Niu, Z., Datla, R., Duguid, S. Development and analysis of EST-SSRs for flax (Linum usitatissimum L.) Theoretical and Applied Genetics, 2009, v. 119 p. 53-63.

6. Doyle, J.J., Doyle, J.L. A rapid DNA isolation procedure for small quantities of fresh leaf tissue. Phytochemical Bulletin, 1987, v. 19 p. 11-15.

7. Cloutier, S., Ragupathy, R., Niu, Z., Duguid, S. SSR-based linkage map of flax (Linum usitatissimum L.) and mapping of QTLs underlying fatty acid composition traits. Melecular breeding, doi:10.1007/s11032010-9494-1.

8. Peakall, R., Smouse P.E. GENALEX 6: genetic analysis in Excel. Population genetic software for teaching and research. Molecular Ecology Notes, 2006, v. 6 p. 288-295.

9. Tamura, K., Dudley, J., Nei, M., Kumar, S. MEGA4: Molecular Evolutionary Genetics Analysis (MEGA) software version 4.0. Molecular Biology and Evolution 2007, v. 24 p. 1596-1599.

10. Rungis, D., Bérubé, Y., Zhuang, J., Ralph, S., Ritland, C.E., Ellis, B.E., Douglas, C., Bohlmann, J., Ritland, K. Robust simple sequence repeat (SSR) markers for spruce (Picea spp.) from expressed sequence tags (ESTs). Theoretical and Applied Genetics, 2004, v. 109 p. 1283-1294.

Anotācija. Latvijā jau izsenis ir kultivêti lini, un linu selekcija Latvijā tika veikta līdz 20. gadsimta septindesmitajiem gadiem, lìdz tā tika apturēta. Kopš 1992. gada linu selekciju Latvijā ir atjaunojis Latgales lauksaimniecības zinātnes centrs (LLZC) un veicis Latvijas linu šķirņu sēklu repatriāciju no vairākām pasaules gēnu bankām. LLZC šobrīd atrodas kolekcija, kurā ir 497 šķirnes un 9865 līnijas un hibrìdi, kas izveidoti kopš 1993. gada. Latvijas linu raksturošanai mēs izmantojām DNS marķierus, genētiskās daudzveidības un līniju savstarpējās radniecības izvērtēšanai, kā arī funkcionālā polimorfisma izpētei. Mēs esam izmantojuši mikrosatelītu (SSR) markierus, kuri izveidoti no genomiskām un ekspresētām DNS sekvencēm. Ar DNS marķieriem iegūtie rezultāti tika izmantoti, lai noteiktu Latvijas linu genēêtisko polimorfismu un genētisko radniecību. Iegūtie dati tika salīdzināti ar LLZC veiktajiem lauka izmēgénājumu rezultātiem. Ar agronomiski nozīmīgām īpaš̉̆bām saistītu DNS marķieru lietošana pal̄̄dzēs linu selekcijai Latvijā. DNS marķieru

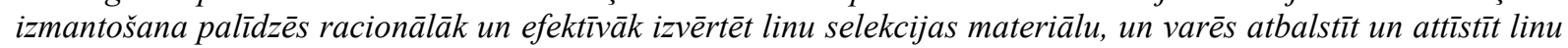
selekciju Latvijā.

Atslēgas vārdi: linu selekcija, DNS marķieri, aprakstīšana un izvēertēšana. 